\title{
Microplastic pollution and its impacts on marine life and human health: a literature review
}

\author{
Wellington Santos de Andrade ${ }^{1 *}$; Rayana Carla Silva de Morais ${ }^{2}$
}

1 Department of Biology, Biological Sciences Center, Academic of the Full Degree Course in Biology of the University Center of Vitória de
Santo Antão (UNIVISA), Vitória de Santo Antão, Brazil.
2 Department of Biology, Biological Sciences Center, Professor of the Full Degree Course in Biology of the University Center of Vitória de
Santo Antão (UNIVISA), Vitória de Santo Antão, Brazil
E-mail adresse: Wellington081918@gmail.com (Wellington Santos de Andrade), rayanacarla@univisa.edu.br (Rayana Carla Silva de Morais)
${ }^{*}$ Corresponding author

To cite this article:

Andrade, W.S.; Morais, R.C.S. Microplastic pollution and its impacts on marine life and human health: A literature review. International Journal of Sciences. Vol. 1, No. 1, 2021, pp. 30-35.

Received: 01 25, 2021; Accepted: 01 27, 2021; Published: 03 15, 2021

\begin{abstract}
Microplastics are fragments up to $5 \mathrm{~mm}$ in size that are polluting the oceans due to anthropic action, impacting the lives of marines and humans. The aim of this article is to inform how microplastics are generated and what are the impacts they cause to organisms. A review was carried out through works available in the databases available on the Internet. Microplastics cause negative physical effects, preventing the absorption of nutrients, due to the accumulation of these particles in the organs of the digestive system of marine organisms. In humans, particles smaller than $20 \mu \mathrm{m}$ are likely to penetrate the organs. Even smaller particles are able to move through cell membranes, blood brain barriers and placenta. Therefore, the awareness of the population through environmental education is still the main alternative for habits to be modified, and thus improve the quality of survival of planet Earth.
\end{abstract}

Keywords: Microplastics. Microplastics in food. Microplastics in the oceans.

\section{Introduction}

Pollutants are widely distributed in every ocean on our planet, and can be found from the ocean surface to the deepest environments on earth, such as the abyssal trenches. These pollutants range from small plastics to radioactive contamination, polluting marine micronutrients, or even large areas with the oil spill, that can be seen from space (ELIAS, 2015).

One of the most well-known and identified pollutants is plastic. From the moment that the plastic material appeared, at the beginning of the twentieth century, we began to have plastic as an indispensable item in our daily lives, so that all, or almost all the things we consume is composed of plastic. Plastic is produced from synthetic polymers, which are mainly derived from fossil fuels, and can have as properties the lightness, durability and thermal and electrical insulation of low cost. Plastic has replaced materials such as leather, wood, metals and natural fibers, being a great alternative for industry and commerce, bringing many benefits to people around the world (CESA, 2017).

Having been the plastic created initially by the Belgian chemist Baekeland in 1909, through formaldehyde-phenolic resins, forming bakelite, which was the first type of plastic, from this made its exploitation only increased, from there to days, because its isolated properties, were, and are quite useful for the industry, especially the electrical industry. During World War II, plastic production increased considerably in Europe due to the manufacture of polyvinyl polychloride (PVC), used to replace natural rubber, in some cases (PIATTI; RODRIGUES, 2005).

However, the high consumption of plastics by the current society has generated a huge environmental concern due to the exaggerated amount of waste formed through this material. According to Horton et. Al. (2017) and Andrady (2017), world production of plastics has grown significantly in recent years, from 1.5 million tons in 1950 to more than 300 million tons in 2017. Besides, according to Hoornweg, et.al. (2013), it is speculated that the increase in waste production in the world will accompany population growth, which it estimates could reach the contingent of 9.2 billion inhabitants in 2050.

Small pieces of plastic floating on the ocean surface were found and scientific reports were first obtained in 1970 (CARPENTER et al. 1972). Being present in beaches, surface waters, throughout the water column and in sediments, fragmented plastics permeate even the most 
remote of marine environments, being caused by its use and its unbridled production. Another problem with plastic is what we call microplastics. We define microplastics as any particle smaller than $5 \mathrm{~mm}$ and can be classified into primary and secondary. Primary microplastics are all those that are specifically produced to have a size smaller than $5 \mathrm{~mm}$ for some particular purpose. The secondary are microplastics that come from the fragmentation or degradation of a larger plastic object. According to studies, all marine organisms are at high risk when ingesting microplastics. Because it has an almost imperceptible size, the vast majority of aquatic organisms end up ingesting these particles together with their food. Microplastics negatively affect organisms and their physical-chemical mechanism (DA LUZ, 2018).

A report released by the UK government's science department indicates that by 2025 the oceans will be three times more polluted than they are currently (BOUCHER; FRIOT, 2017). According to Thevenon; Carroll, carroll, carroll. Sousa (2014), of all microplastics that pollute the oceans, about two thirds come from vehicle tires and microfibers that are released during washing clothes.

Microplastics are also an evil to human health. According to Liebezeit, G; Liebezeit (2014) was detected as microplastics in 24 German beer brands, and 16 out of 17 industrial salt brands were analyzed in eight countries: Australia, France, Iran, Japan, Malaysia, New Zealand, Portugal and South Africa, according to Karami, et al (2017). The human being comes into contact with microplastics when they feed on various dishes, through some drink, when breathing, or even when using exfoliating products, occurring the absolution of chemical additives, such as dyes and antioxidants, which join the cells and tissues. To prove all this, according to Harvey and Watts (2018), a study by the Austrian Environmental Agency analyzed the feces of eight individuals from Europe, Japan and Russia, and were able to detect microplastics in human fecal excretions. The treated waters that have microplastics come from the use of household products, such as cleaning and cosmetics, which in turn are destined to the sewers, which end up not being removed with conventional techniques. The presence of microplastics has already been verified in studies with a sample of drinking water from traditional plastic bottles, in addition to glass and beverage bottles in boxes. The particles found ranged between 5 and $20 \mu \mathrm{m}$. Among these particles, the polymers of the types Polyethylene terephthalate (PET), Polyethylene (PE), Polystyrene (PS) and Polypropylene (PP) stood out in consecutive order (CAIXETA; CASKET; MENEZES FILHO, 2018). In view of the above, this article aims to conduct a literature review in order to understand how microplastics are generated and to inform about the impacts they cause to the oceans, human health and the environment as a whole.

\section{Methodology}

This is a literature review study, in order to review the contents available on the proposed theme.

We searched and analysed works available in the research databases: Scielo, Google academic, Virtual Health Library, Lilacs, Science direct, PAHO Brazil, Scientific, UN, PubMed and Education Resources Information Center. These searches were conducted from March to September 2020, using the following descriptors: Microplastics; pollution by microplastics, microplastics in the oceans; plastics in the environment; plastic waste; microplastics in food; microplastics in the marine environment; ingestion of microplastics; effects of microplastics.

Based on the abstract and title, a refinement was performed and only articles more consistent with the theme initially proposed were selected. Two files were selected in the Scielo database, four in the academic Google, one in PAHO Brazil and one in PubMed, in English, Spanish and Portuguese, published between 2011 and 2020. Theses, dissertations, monographs and simple abstracts published in a congress were excluded. The extracted data were used descriptively to observe, tell and describe the impacts of microplastics on the marine environment and human health.

\section{Results and Discussion}

What is observed of plastic garbage floating in the sea is only a small part of the actual amount that exists, because more than two thirds of these garbage end up at the bottom of the oceans, while only a third is taken to the beaches. Of all the plastic waste in the oceans, about 250,000 tons are fragmented into more than 5 trillion pieces smaller than $5 \mathrm{~mm}$ : the microplastics. All this represents not only plastic pollution, but also a huge dumping of millions of tons of chemical additives into the oceans (GALLO, et. al. 2018).

Plastics are produced with the intention of supporting varieties of use, and are not biodegradable, but abrasion and photodegradation contribute to their degradation by sharding and fracture. As plastic ages and fragments, microplastics tend to sink and become available to benthic organisms. Microplastics, because they are the same size as the food of many species of these organisms, end up confused and ingested. Many species of birds and marine mammals have been found with microplastics in stomach contents over the years, and this is probably due to the result of transmission via the food chain (SOBRAL; MARTINS, 2011).

Marine organisms cannot differ from what is a microplastic and what is a nutrient, so if the microplastics are next to an algae or any other nutrient, those organisms will ingest. If a crustacean eats something with microplastics, a food chain will be generated with these particles, because surely this animal can be prefaced by another, passing on the particles, until it reaches humans directly or indirectly.

In fish, microplastics cause negative physical effects, preventing the absorption of nutrients, due to the accumulation of these particles in the organs of the digestive system, in addition to damage to gastrointestinal tissues and physiological changes, which cause a change in the behavior of these animals (OLIVEIRA; CORREA; SMITH, 2020). If microplastics are to replace plankton in the oceans, it is likely that not only the behavior, but also the growth of fish, will be altered due to the effects of the sleep (CRITCHELL; HOOGENBOOM, 2018).

In humans, the fate of microplastics will depend on particle size. Around $90 \%$ of the particles are excreted in the 
faeces, but microparticles smaller than $150 \mu \mathrm{m}$ are able to move from the intestine to lymph and circulatory systems, and particles smaller than $20 \mu \mathrm{m}$ may be likely to penetrate the organs. Even smaller particles are able to move through cell membranes, blood brain barriers and the placenta. The body's reaction to the presence of these particles generates a number of responses, such as immunosuppression, immune activation, and unusual inflammatory responses. Microplastics are classified as toxic vectors and facilitate the transfer of chemicals in organisms consumed by humans (NAIDOO; RajkarAN; SERSHEN, 2020).

In addition to the risks of ingesting microplastics, as they may be present in food and water, there is also a risk of inhalation exposure. Microplastics, after inhalation, can cause respiratory and cardiovascular diseases, considering low exposure concentrations, and high concentrations can cause lung cancer (OLIVATTO et al. 2018).

It can be said that the human being is held hostage by his own acts. It generates garbage every time something is consumed, and if that garbage is not disposed of correctly, it can come back in the worst way. In the case of microplastics, these may have been a plastic bag that has degraded over many years and returned to tables, waters and airs in a reduced way, being ingested and breathed inconspicuously.

The World Health Organization (WHO) indicates that microplastics have already been detected not only in seawater, but also in wastewater, freshwater, food, drinking water and air. Microplastics enter aquatic freshwater environments in various ways: mainly by surface runoff and wastewater effluents, whether treated or untreated. Also, by combined overflows of sewers, industrial effluents, degraded plastic objects, and atmospheric deposition. There are limited data that quantify the contribution of each different input and its sources. Limited evidence indicates that some microplastics found in drinking water may come from tap water treatment and distribution systems or bottling of bottled water. Some systematic literature reviews have identified 50 studies that detect microplastics in freshwater, drinking water or effluents (WORLD HEALTH ORGANIZATION, 2019).

Synthetic textiles are abrasioned during washing of clothes in homes and industrial laundries, generating the microfibers that detach from clothes, and these are types of primary microplastics. The microfibers are then drained into the sewers, being transported to rivers and oceans. These microfibers are usually made of polyester, acrylic, elastane or polyethylene. Other types of common microplastics come from toiletries such as exfoliation products, for example. Some products contain more plastic in their composition than their own packaging. This amount represents about $10 \%$ of its total weight, and thousands of plastic particles per gram of the product. The use of these toiletries directly introduces microplastics into the wastewater flows of hotels, residences, hospitals and sports facilities, which also includes beaches. Some other sources that generate microplastic particles by abrasion and weathering are kitchen utensils, shoe fronts, artificial lawns and building coverings (BOUCHER; FRIOT, 2017).

All this that has been treated so far shows how impactful microplastics are in the environment. They affect not only the waters and soil, but also the organisms that inhabit these sites, including humans. Discussing microplastics and their impacts on the environment is too important, as it is a subject that is still neglected by many. The studies conducted so far show several reasons for rethinking the acts in everyday life. More research should be conducted on microplastics, and more information and environmental education activities need to be offered to people to understand the severity of this issue. There is still little scientific information on how to prevent pollution by microplastics, so studies on this topic on the issue of prevention are of paramount importance.

\section{Conclusions}

Based on what was addressed in the results of this article, it can be concluded that the effects and presence of microplastics in the oceans is a topic of total relevance with a global impact. There are many studies on these plastic particles, but there is little knowledge of this subject by society, which leads us to understand that people still need to be educated environmentally, so that they will avoid pollution by microplastics in the environment, and even take action on it, changing their habits on a daily life.

The move to a planet with less plastic begins when it becomes a habit to avoid plastic. This can be done when we avoid buying clothes made of this material, since when washing, the microfibers released during washing seep through the drains and go into the water flows. Preference should be given to clothes made of cotton, which generate a much smaller impact compared to clothes made of polyester, elastane etc. You can also avoid plastic when using reusable bags in grocery shopping. Separating waste for recycling is also an important step, as well as reusing plastic materials and reducing if possible. Avoiding primary microplastics, those found in toiletries, for example, is also an important step towards change.

If the population can avoid the primary microplastics, there will still be the secondary ones, but that by following the rule of 8 R's: (Reflect, Reduce, Reuse, Recycle, Respect, Repair, Take Responsibility and Re-pass), much of the problem would be solved, and much of the environmental impact would be minimized. The highlight of the awareness of the world's population is still environmental education, so that one can see the environmental impacts and modify common habits predicting a better quality of survival of planet Earth.

\section{Acknowledgements}

I thank my family who helped me in this important phase of my life, my friends, Daniel, Claudiane, Emily, Felipe and Lucas for their support and friendship during these four years of college. I also want to thank my teachers who helped me get here. Thank you very much!

\section{References}

[1] ANDRADY, A. L. The plastic in microplastics: a review. 
Marine Pollution Bulletin, v. 119, p. 12-22, 2017.

[2] BOUCHER, J., FRIOT, D. Primary microplastics in the oceans: a global evaluation of sources. Gland, Switzerland: IUCN, v. 3, p. $43,2017$.

[3] CAIXETA, D. S., CAIXETA, C. F., MENEZES FILHO, F. C. M. Nano e micróplasticos nos ecossistemas: impactos ambientais e efeitos sobre os organismos. Enciclopédia Biosfera, v. 15, n. 27, p. 24, 2018

[4] CARPENTER, E. J. et. al. Polystyrene spherules in coastal waters. Science, v. 178, n. 4062, p. 749-777, 1972.

[5] CESA, F. S., RAMOS, J. B., TURRA, A. Microplásticos têxteis: emissão de fibras sintéticas na lavagem doméstica. Dissertação (Mestrado em Ciências) - Programa de Pós-Graduação em Têxtil e Moda, Escola de Artes, Ciências e Humanidades, Universidade de São Paulo. São Paulo, 155 p., 2017.

[6] CRITCHELL, K., HOOGENBOOM, M. O. Effects of microplastic exposure on the body condition and behaviour of planktivorous reef fish (Acanthochromis polyacanthus). Plos one, v. 1, p. 1-19, 2018.

[7] DA LUZ, J. A., Caracterização de microplásticos em conteúdo de tratos gastrointestinais de peixes do estuário do rio tramandaí litoral norte do Rio Grande Do Sul através de digestão de tecidos biológicos. Monografia (Curso de Ciências Biológicas: Ênfase em gestão ambiental marinha e costeira) Universidade Federal Do Rio Grande Do Sul. Porto Alegre, 17.p, 2018.

[8] ELIAS, R. Mar del plástico: una revision del plastico em el mar. Rev. Invest. Desarr., Pesq. n. 27, p. 83-105, 2015. Disponível em: <https://www.inidep.edu.ar/wordpress/?page_id=10855>. Acesso em: 5 de abril. 2020.

[9] GALLO, F. et. al. Marine litter plastics and microplastics and their toxic chemicals components: the need for urgent preventive measures. Environ Science Europe, v. 30, n. 13, p. 2-14, 2018.

[10] HARVEY, F., WATTS, J. Microplastics found in human stools for the first time. The Guardian, 22 out. 2018. Disponível em: $<$ https://www.theguardian.com/environment/2018/oct/22/micr oplastics-found-in-human-stools-for-the-firsttime?fbclid=IwAR3Eep-zHg5r5s_XSIsbu7CWm838z-

VJdADjwioQ8GqhughR4_J2SaWopHo.> Acesso em: 20 de Set. 2020 .

[11] HOORNWEG, D., BHADA-TATA, P., KENNEDY, C. Environment: waste production must peak this century. Nature, v. 502, p. 615-617, 2013.

[12] HORTON, A. A., SVENDSEN, C., WILliaMS, R. J., SPURGEON, D. J. Large microplastic particles in sediments of tributaries of the river thames, uk-abundance, sources, and methods for effective quantification. Marine Pollution Bulletin, v. 114, p. 218-226, 2017.

[13] KARAMI, A., GOLIESKARDI, A., KEONG CHOO, C. et al. The presence of microplastics in commercial salts from different countries. Scientific Reports, v. 7, p. 1-9, 2017.

[14] LIEBEZEIT, G., LIEBEZEIT, E. Synthetic particles as contaminants in german beers, food additives \& contaminants. DEUTSCHE LEBENSMITTEL-RUNDSCHAU v. 31 n. 9, p. 1574-1578, 2014.

[15] WORLD HEALTH ORGANIZATION, Microplastics in drinking-water. Disponível em: < https://apps.who.int/iris/bitstream/handle/10665/326499/9789 241516198-eng.pdf?ua=1 >. Acesso em: 10 de out. 2019.
[16] NAIDOO, T., RAJKARAN, A. SERSHEN, Impacts of plastic debris on biota and implications for human health. A South African perspective. Marine Plastic Debris. Review Article, v. 116, n. 5, p.1-8, 2020.

[17] OlivatTO, G. P. et. al. Microplásticos: Contaminantes de preocupação global no antropoceno. Rev. Virtual Quim., v. 10, n. 6, P. 1968-1989, 2018.

[18] OLIVEIRA, C. W. S., CORRRÊA, C. S., SMITH, W. S. Food ecology and presence of microplastic in the stomach content of neotropical fish in an urban river of the upper Paraná River Basin. Rev. Ambient. Água, v. 15, n. 4, p. 2-11, 2020.

[19] PIATTI, T. M., RODRIGUES, R. A. F. PLÁSTICOS: Características, usos, produção e impactos ambientais. (Conversando sobre ciências em Alagoas) Universidade Federal De Alagoas, Maceió: EDUFAL, p. 50, 2005.

[20] SOBRAL, P., MARTINS, J.F.J. Microplásticos nos oceanos um problema sem fim à vista. Artigos de Revisão, v. 3, p. 1221, 2011.

[21] THEVENON, F. CARROLL, C. SOUSA, J. Plastic debris in the ocean: the characterization of marine plastics and their environmental impacts, situation analysis report. Gland, Switzerland: IUCN, v. 52, p. 6-52, 2014. 